\title{
The Impossibility of Global Citizenship
}

\author{
Patricia Burke Wood \\ York University
}

\begin{abstract}
In this essay, I dispute the possibility of global citizenship, presently receiving support in activist circles (academic and otherwise) and educational communities. I attempt to dispel the celebratory conceptualization of citizenship as a status benevolently awarded by the state, and the state as a reasonable and moral partner in the exchange. Global citizenship is challenged on two fronts: as an impractical (and undesirable) scale of government, and through a critical exploration of the production of citizenship as a technology of governance by the state whose language of equality not only serves to include and empower, but also to exclude and justify such exclusion. Nonetheless, in support of those organizing to counter the negative effects of neoliberal globalization, I conclude that non-scalar thinking about governance, and a broader understanding of being political than is commonly captured by citizenship, offer strategic possibility for civil society.
\end{abstract}

Power concedes nothing without a demand. It never did and it never will. Find out just what any people will quietly submit to and you have found out the exact measure of injustice and wrong which will be imposed upon them, and these will continue till they are resisted with either words or blows, or with both.

Frederick Douglass (1857/1985, p. 204)

...I want to strengthen our ability to block the privilege of citizenship to those with a criminal record. After all, British citizenship is a privilege, not a right.

Jacqui Smith, Home Secretary, United Kingdom (Government News

Network, 2007)

Patricia Burke Wood is Associate Professor of Geography at York University and can be reached at pwood@yorku.ca

Acknowledgement

An earlier version of this paper was delivered at the CHANCE conference 'Embracing global citizenship' at the University of Toronto, February 10, 2007. I offer my thanks to CHANCE, Engin Isin, Scott Prudham, Julie Young, James McLean, Mike O'Sullivan, Karen Pashby, and a further anonymous reviewer, for their valuable feedback on earlier versions of the paper. 


\section{Introduction}

In this essay, I dispute the possibility of "global citizenship," and attempt to dispel the simplistic understandings of citizenship as a status benevolently awarded by the state, which I fear underpin the idea. This connotation of "citizenship" is prevalent in Western democratic societies, where the institution (along with democracy) is exhorted as a privilege of political enlightenment. Citizenship in these societies is a cherished and coveted status: it means you are included and, significantly, equal. Citizenship provides the foundation for a democratic society, as it is the basis for fundamental political rights such as the vote. Holding or achieving this status carries the subtext of a reasonable and noble exchange: in return for behaving conscientiously, you are rewarded with rights and protections. Oaths of citizenship in Western states and other democracies (such as Canada, the United States, the United Kingdom, Australia, India, and Singapore) speak of faithfulness and fulfillment of duties, such as the promise to observe the law: i.e. obligations of the citizen to the state. The state's reciprocal commitment to the citizenry resides in its constitutional articulations of rights and liberties. Occasionally, the reciprocity of the arrangement surfaces plainly, as it did in Canada in 2006, for example, over the dual citizenship (Canadian/Lebanese) held by many residents of Lebanon. The then Minister of Citizenship and Immigration Monte Solberg observed, "If we're in a situation where somebody's absent, isn't paying taxes but is going to be using our social programs down the road, I think Canadians would feel that that is unfair," (CBC News, 2006). The rights and entitlements (measured here partly in terms of their financial cost) derived from citizenship have their cost, and yet the implication is clearly that the status merits the cost, that citizenship has a value which must be protected.

Citizenship thereby confers its positive connotation to the Western democratic state, and citizens in turn identify with the state and with the positive attributes they have created for it. It is through citizenship that residents (and, in some cases, non-residents) directly participate in the creation and recreation of the state, and adhere their own fate to that of the state. Indeed, as Faizullaev (2007) states, "State related legal identity is citizenship" and, as he emphasizes, this identification may occur "legally, morally, culturally, politically and psychologically;" he goes so far as to argues that citizens have a sense of having "interpersonal interactions" with the state (p. 549). In this relationship, the state commonly dissolves into a singular, holistic entity (and it shall be treated as such for the purpose of this argument, for it is the existence of a state apparatus that concerns us here, not the specifics of a government) and reduces to a monolithic, paternal figure, often personalized to express positive or negative attributes or feelings 
towards its citizenry and other states (Faizullaev, 2007; see Neumann, 2004 and Wendt, 2004 for a full debate as to whether the state literally is a person). In securing their borders and screening immigrants, states demonstrate themselves to be responsible actors in the protection of the privilege of citizenship.

The present enthusiasm for an idea of "global citizenship" in activist (academic and otherwise) and educational communities derives from this celebratory conceptualization of citizenship as a status, and the state as a reasonable and moral partner in the exchange - even as its promoters express reservations about the acts of individual governments. In legal and politicalsociological scholarship there lies also an optimism that sovereignty (if not precisely citizenship) "can be stripped away from the idea of fixed borders and territories and thought of as, in principle, an attribute of basic cosmopolitan democratic law which can be drawn upon and enacted in diverse realms..." (Held, 2002, p. 32). Scholars such as Barbara Arneil (2007) argue that "the dual forces of economic globalization... and the rise of American empire" make global citizenship a "required" response (p. 302). For some, the idea is nothing short of exciting: "Globalism's optimists suggest that rule of law may become unhinged from the nation and its sovereignty. (...) This potential is so breathtaking it is worth considering imaginatively and fostering through advocacy, even if its theoretical supports remain shaky" (Dauvergne, 2004, p. $615)$.

In all these cases, the hope is that barriers between nation-states might be transcended by a commitment to the higher cause of our common humanity, providing a "brighter side" to globalization, perhaps even the antidote to poisonous aspects of the global economy, as Arneil advocates. Global citizenship implies the harnessing of an enormous collective of human resources and good will. Fully embraced, global citizenship will surely put an end to war, poverty, racism, gender inequality, environmental degradation, the exploitation of children, HIV/AIDS, and any other scourge we might wish to extinguish.

The mission statement of CHANCE, a student organization at the University of Toronto that assembled a February 2007 conference, "Embracing Global Citizenship," confirms these impressions, and reveals the ways in which students in particular have derived inspiration from this idea and played a strong role in its perpetuation. Its articulation is not unique, but strongly representative of a larger movement to which many individuals, organizations, and institutions subscribe, from NGOs such as Oxfam (Oxfam Education, 2007) to mega-corporations such as Microsoft (2007). The CHANCE statement reads, in part: 
The mission and foundation of Chance is fostering global citizenship within youth and establishing the platform necessary to live and act beyond borders. ... With this idea, we have focused on several key issues that have defined our world beyond borders, and are pressing issues of our generation; issues of migration and immigration, sustainable development and the environment, nuclear war, poverty, HIV/ AIDS among other health related issues, cultural consciousness and globalization. With a constantly changing world and the onset of globalization, which may, or may not be a beneficial entity, it is critical for students and youth to develop a sense of global responsibility and a global consciousness, and embrace the world that we all live in. As the future leaders of the new millennium, it is vital that we as students can understand the importance of global citizenship in order to effectively change the world we live in for a more peaceful and equitable world. (CHANCE, 2007)

Such goals and sentiments unquestionably inspire. Citizenship, however, is not a synonym for "consciousness" or "responsibility." While I do believe in the potential enrichment and political advantage from the transnational organization of social movements, international political alliances, and an environmental consciousness that is not limited by national borders (in recognition that neither pollution, nor pollen, nor a black bear will stop for customs agents), it is misplaced and potentially counterproductive to advocate these positions under the banner of "global citizenship." Global citizenship is an impossibility. There are two reasons: first (as others have argued), because citizenship functions as part of a formal political structure that is absent at the global level; second, because I remain skeptical about citizenship as an unambiguously emancipatory, empowering institution. I view citizenship instead as a technology of governance enacted by the state in which "citizens" (regardless of formal status) participate to varying degrees (Isin \& Wood, 1999). As such, citizenship is an institution with as many pitfalls as windfalls. Citizenship may serve as a discursive device to assist in the creation of political space, but it may (just as easily, if not more so) serve to regulate and dis-empower the individual even as the state alleges to empower, liberate, and trust that same person.

In the paragraphs that follow, I elaborate on the reasons for which I believe global citizenship is an impossibility; nonetheless, I want to assert my clear and strong support for student-led and other initiatives that take our common humanity and collective responsibility as their premise of social and political organization. In a democratic society, civil society contains the 
potential for political engagement and activism through actions that reveal and make productive the state-citizen relationship, which in turn creates citizenship in practice. If "citizenship" is to be invocated in grass-roots organizations, it may be more logical to remove it entirely from scales of governance, and modify it as "cosmopolitan citizenship." Such terminology would maintain the ground-up mindset and cosmopolitan ethic that frames the activism in the first place. Still more productive might be to use words such as "consciousness" or "activism;" the latter in particular would dissociate political action from corporate branding exercises that employ "global citizenship." In any event, the essay closes on a more optimistic note, with some thoughts about the possibilities for achieving the stated goals of "global citizenship" through localized acts of citizenship which are real and transformative.

\section{Globalities}

It is commonplace by now to acknowledge that what we commonly call globalization is not a new and original phenomenon unique to the late $20^{\text {th }}$ or early $21^{\text {st }}$ century. There have been global networks of trade, global flows of people for hundreds and thousands of years. What is frequently raised to distinguish the present configuration (since about 1973) is that, due to particular technologies, we are able to move capital, people, and information at an exponentially faster rate and greater volume than previously. More significantly, however, we have achieved this mobility and flexibility via a set of structures and practices that have transformed labour markets, state tariff barriers, property rights, environmental regulations, intellectual property and so on (McCarthy \& Prudham, 2004; Peck, 1996, 2001; Sonnenfeld \& Mol, 2002). This set of restructuring practices is what constitutes neo-liberalism, and it properly distinguishes the character of today's "global economy" from other global economies at earlier points in history.

This social, cultural, economic, and political restructuring has been actively facilitated by individual states, by corporations, and by associations such as the IMF, the WTO, and the World Bank. While states send political representatives to these latter institutions, they are not formal political structures. None of them act in a democratic, representative fashion. Some have argued that the nation-state has consequently been "hollowed out" (Jessop, 1994), but these organizations have not replaced the nation-state. Not only do the usual political lines of national borders remain on the maps, but the state has not absented itself from or in this process. Quite to the contrary, the state has been deeply embedded in these negotiations and has actively facilitated the consequent reconfigurations. 
Due to the state's participation (we might say complicity), neoliberalism has commodified and otherwise eroded the rights of its citizens (Falk, 2000). Reduced oversight and regulation on the part of the state through the neoliberal transformations noted above have shifted the responsibility for safety and well-being to corporations (to behave conscientiously) and to civil society (for individuals to inform and take care of themselves). If the state does not monitor or even regulate, for example, the environmental safety of industrial emissions, then the individual business becomes socially (not necessarily legally) responsible for such monitoring and residents must take it upon themselves to become aware of the potential dangers in their area. Commonly, the community lacks the knowledge, access, and time to conduct their own research at the same standards achievable by the state or the industry (see Walcott, 2003 for details of the challenges and frustrations).

Despite such difficulties, hope for a "global citizenship" to counter the nation-state's withdrawal from protection of its citizens comes from the realization that the pathways of infrastructure through which capital, people, and information flow for the purposes of capitalist accumulation also create spaces of possibility for movement for other purposes. As Jelin (2000) notes, "An increasingly dense web of worldwide exchanges, facilitated by Internet and other means of communication, results in the realization that governments do not have a monopoly on information flows" (p. 51). Protesters can use the internet to organize massive gatherings; refugees can take advantage of transoceanic flights; celebrity activists can harness the mass media to raise awareness and funds to fight poverty and disease; and so on. These connections, roads to freedom, and popular mobilizations are real. They truly connect, engage, and even liberate people. The technological infrastructure that spans the globe offers the possibility of a global mobilization of ordinary people, resistance on a massive scale.

Despite the optimism we may derive from civil society's use of this global infrastructure, if it remains in place for those resisting the neoliberal status quo, then that infrastructure will remain in place for those who created it and maintain it in the first instance. It will continue to serve capital and the neoliberal state. Furthermore, the political and financial infrastructure that constructs and governs, for example, the internet retains the ability to exert its authority to exclude what it deems undesirable. The anarchistic democracy of cyberspace continues to be tied to the hardware reality of servers governed by something other than democracy. Examples of intervention and control are numerous, such as China's screening of internet access (and Google's collusion), and Russia's successful pressure on the Lithuanian, Finnish, and Swedish governments to shut down Chechen websites hosted on private servers in their countries. 
There is no global political organization that can represent, advocate for, and protect the rights of its so-called citizens. Rights are politically contingent and need to be backed by a state (Janoski, 1998). As Isin and Turner (2007) have recently written:

A citizen exists originally within the political confines of a state, and until a genuinely global state exists that has sovereign powers to impose its will, it is misleading to talk about the "global citizen."...Citizenship does extend beyond the state but through institutions that cannot be captured by the concept "global citizen." (p. 14)

Possibilities for citizenship "beyond the state" here do not refer to citizenship "above the state" but rather to conceptualizations removed from such "scalar thought" (Isin, 2007, p. 211). We shall return to this idea in the conclusion. Here, it is important to note that there are hard political realities to face (Halliday, 2000): even international law and the United Nations are designed, operated, and funded by nation-states. Global political organizations with any sovereignty or powers of enforcement do not and can not fully transcend that political order of the nation-state nor divorce themselves from it; if they do, they cease to function. No state elects to put itself out of business. States only yield to an international body when they are compelled to do so - in which case, they still act in their best interests. The gains in international acceptance and support outweigh the domestic gains in resisting and ignoring international judgment. Acting in its own best political interests, to secure its greatest chance to survive and thrive, is what the state always seeks to do (Krasner, 1999, makes a similar, but more Machiavellian, argument about individual rulers rather than states). To place our faith in such institutions as the UN or the World Court suggests these political institutions could negotiate successfully with the global economic organizations that have successfully territorialized much of the world. While international civil society has successfully assisted in the redistribution of wealth and struggles for justice, there is no basis for believing that a global government would defend the marginalized and dispossessed more effectively than existing statesespecially those elected by their citizens - presently do. Moreover, the argument implicitly states that the problem (the ills wrought by neoliberal globalization) is principally one of scale, and that it can successfully be attacked by matching that scale; as Muetzelfeldt and Smith (2002) have noted, however, institutions of global governance may frustrate or facilitate civil society action, just like states.

The leverage of a state's sense of obligation and desire for legitimacy is the most secure weapon activists wield. Even in transnational activism, possessing citizenship is not essential. Michael Peter Smith's (2001) work 
confirms that transnational networks may be profitably mobilized and further documents that official citizenship or even legal status is not necessarily a prerequisite for successful outcomes of protest. This citizen-state relationship emerges from the existence of democracy and the related principle of accountability, rather than the actual institution. This appears to counter Arneil (2007) and others who argue for the urgency of a parallel form of governance and status in order to contend with the neoliberal global economy.

The temptation to raise the question of the possibility of global citizenship from below - citizens "jumping over" the nation-state to function as a kind of United Nations or united humanity - appears understandable. The desire for global citizenship itself implies that the cumulative series of national citizenships fails to get the job done. What job needs to be done? On the surface, this is easily answered: clearly the goals set out by CHANCE are what need to be done. The search for global citizenship is motivated, at least in part, by a legitimate frustration with the nation-state's apparent inability or unwillingness to act, and/or a sense that the state has become inaccessible to those pushing for change.

This impetus for global citizenship, then, in some ways mirrors multinational corporations' parallel "jumping over" national governments and markets to access raw materials, labour pools, and consumers around the world. Activists believe that a similar global mobilization of "citizens" will increase their leverage. Certainly, when a massive scale of protest achieves increased media coverage, which in turn increases the embarrassment factor that is often key to bringing about change, this may be interpreted as increased leverage (Jelin, 2000). Leverage, however, does not constitute citizenship. Unelected, even non-political, organizations can and do respond to public protest, but only in an ad-hoc fashion; corporations in particular are unable to do otherwise (see Bakan, 2004, for an elaboration of the corporation's singular and psychopathic accountability to its shareholders, i.e. profit). Citizenship is rooted in the establishment of rights and responsibilities - and mechanisms to enforce them - that would transcend individual negotiations. Citizenship allocates a space for a political process that legitimately involves the citizen; state responses to protests against meetings of global organizations such as the WTO strongly contest the legitimacy of citizen public action (Wainwright, Prudham, \& Glassman, 2000).

\section{Technologies of Governance}

One of my favourite academic pastimes is to wonder why we have certain rights in our Constitution (specifically the Canadian Charter of Rights and Freedoms, but this game can be played with any country's 
institutionalization of rights), but not others. I ask students, for example, why do we have the right to freely and independently contract our labour, but not the right to shelter? Why do we have the right to express ourselves freely, but not the right to eat? Why do have the right to vote, but not the right to camp in public? At heart lies the question of the purpose of the creation of rights, and the ways in which populations are governed by them, as much as they may be liberated or empowered. Another of my favourite pedagogical exercises is related to the first, but is more cynically rhetorical: to question the reasons for silence and exclusion in the history of the creation of citizenship rights. Do you suppose that when the state allocated the right to vote only to men, or only to Whites, or only to property owners, that it was an accident or oversight? Do you think, for example, that they meant to include women, but just forgot? Is it possible that no one, even those excluded, understood that they were being excluded and appreciated the significance of such exclusion? Students' first response to such questions is sometimes confusion and even annoyance, until they realize the significance of the intentionality of the state's privileging or exclusion.

These are more than annoying little questions. These kinds of questions comprise entry-points into a critical historical unpacking of the development of citizenship, capitalism, and the nation-state that should radicalize our understanding of how citizenship functions as an institution, and what it means to be political and act politically. There is and has always has been a strategic purposefulness in the state's decisions to provide specific rights, and in their allocation or application to specific populations. A common defense offered by my students and others of historical discrimination is that earlier times were less enlightened; however, there has always been consciousness of and resistance to exclusion and discrimination. Nearly 60 years ago, the sociologist T.H. Marshall (1950) wrote Citizenship and Social Class. In this work, he traced a historical relationship between the development of different types of citizenship rights (such as civil, political, and social) and the development of capitalism. The kinds of rights we hold today in Western democracies did not emerge all in one moment; for the most part, rights were extended to citizens as it best served capital and/or the needs of the state. Education, for example, became a social right when capital needed a literate, skilled workforce. Various populations got the vote when the state needed their allegiance: so men got the vote before women because the state needed the support of men (for things like military service), but did not need (or did not think it needed) similarly to purchase the support of women. When women protested loudly enough and became a public disruption, thereby challenging the state's capacity to govern and keep order-and before and since, Blacks, gays, workers, and so on, have done the same 
thing - only then did the state extend rights to populations it had previously excluded. This point is not to suggest public protest immediately guarantees change (and is not an attempt to oversimplify any of the above rights struggles), but rather endorses Giorgio Agamben's contention that "the voluntary creation of a permanent sense of emergency... has become one of the essential practices of contemporary states"(2005 p. 2). The state excludes portions of the population as a normal course, and often must be strongly and noisily challenged to do otherwise.

The radical qualities of Marshall's work have been frequently overlooked. His chronological order of the emergence of rights should not indicate a Whiggish theory of progress, but lay bare a strategic relationship between capital and the state, and the potential for subsequent strategic activism on the part of citizens. This type of analysis has been taken further by Janoski (1998), whose comparative work on different countries as examples of different forms of democracies has precisely documented the historical contingency of the development of citizenship rights.

Our various founding fathers did not accidentally argue for the rights they did. They chose them - but not due to the inherent, rational superiority of a given political philosophy, but because they were (often personally) wellserved by the rights and freedoms for which they advocated (see Krasner, 1999). As Catherine Mackinnon (1991) has argued, what is deemed to be "rational" is that which justifies and legitimates the status quo. Citizenship as an institution became a way of empowering some people directly at the expense of others. History is replete with examples of legalized privilege and the consequent production of inequality and conflict (one of the more (in)famous examples is the creation and governance of the "difference" of Tutsis and Hutus in present-day Rwanda via the privileging of one group over the other by colonial and post-independence governments; Prunier, 1995). Indeed, it is through such differentiated allocations that difference itself is produced, made meaningful, and sustained. Establishing certain rights for certain individuals and communities thus was (and remains) a technology of governing both the excluded and the included. A discursive discipline hinged on the morality of the "good citizen" (justifying the privileged group) created models of citizenship often impossible to achieve (e.g. maleness, whiteness; see Fanon, 1967). This process entrenches the idea that citizenship is a reward that is earned through good behaviour (see White, 2006), and continues to be reinforced through requirements for naturalization such as the United Kingdom's "good character" condition (Home Office, 2007).

Much good work in citizenship studies focuses on the contradictions between what the state does and the values it alleges to hold, as set out in such documents as the Charter of Rights and Freedoms. Why did Chinese and 
White residents of British Columbia have different rights? Why have gays and lesbians been prevented from adopting children? Again and again, scholars detail the ways in which various communities, such as Natives, Muslims, persons with disabilities, gays and lesbians, have been and continue to be treated less than equally despite our stated moral and legal commitment to do so (Backhouse, 1999; Frazee, 2002; Harring 1998; Lister, 2003). Even Canada's relative success with multiculturalism should not prevent a clear critique of the intolerance and racism exercised by the state, past and present. Throughout its history, the Canadian state has openly ranked and even barred immigrants based on their racial/ethnic origins and their religious faiths (Backhouse, 1999; Wood, 2002; Wood \& Gilbert, 2005). Underpinning many of these works is the often-unspoken faith that these inequalities are anomalies. I am arguing that they are instead the norm, and that they are often enacted through the very institution that purports to prevent them.

Many have pointed out the ways in which Canada's selfidentification as a caring, humanitarian, and multicultural nation clashes with its treatment of migrant workers, refugees, and persons without status (Basok, 2002; Mountz, 2003). Like other Western states with more aggressively imperialist foreign policies, Canada creates what Agamben (2005) identified as spaces and "states of exception" for its refugee populations, as it did for First Nations; both were and are excluded in practice by the terms of their inclusion. Classified as non-citizens and "irregular" migrants, refugees can "legitimately" be denied the full protection of the state (Isin \& Rygiel, 2006; Pratt, 2005). Lack of formal status is invoked even when it is clear that individuals "belong" nowhere else, that Canada is all they know; Canada's refugee and immigration policies include the deportation of those who have lived all but a few months of their lives in Canada. Unlike the United States, Canada even deports minor children who are citizens when their non-citizen parents are deported.

We may critically observe that in the examples of immigrants and refugees, these are not citizens. But notice: historically, there has been littleto-no difference between the treatment by the state of official citizens and those without any legal status. Legal status has not, historically, insulated groups from racist or sexist policies of their governments. The state does not base its treatment on the possession of formal citizenship. We must recognize the actions of the state as intentional and strategic: it does not do what, on moral or even legal grounds, it "must" or "is supposed" to do; it does what it deems necessary.

If we think critically about the role of the state in a capitalist society, we can see that it serves to mitigate as well as justify but, in either event, hide the inequality produced by the capitalist system. Indeed, I would argue it is the institution of citizenship itself, with its overt promises of equality, which is 
used not to provide equality but to hide massive inequality. In the very act of providing rights, the state actively dis-empowers its citizens. The institution of citizenship creates a vocabulary of democracy and equality for the state to employ in legitimating its government. "Citizenship" declares everyone equal; "democracy" ensures inclusion; the material deprivations brought about by capitalism appear, at best, solvable, and at worst, natural or invisible. But if the state declares everyone is equal before it, then inequality, the logic runs, cannot be the fault of the state, nor its responsibility. Even as the state privileges one group over another, its language of the equality of citizens naturalizes the hierarchy and justifies exclusion.

The most common discourse of citizenship by advocates of "global citizenship" is that of "human rights" - ideas and ideals of natural, universal, fundamental, or transcendent entitlements. Such rhetoric can be very effective as affect, but substantively, it is more an abstract distraction or a decorative mask than a tool in the actual battle for rights. Rights are specifically, contingently, politically and actively produced; they are negotiated in specific historical and geographical contexts and circumstances. They are, therefore, the antithesis of politics mobilized by ideas of inherent and universal "human rights." The universalist language of human rights implies a process of moral enlightenment of states: lawmakers "merely" need to adopt these specific protections. A particular law will not provide justice on its own: "[c]itizenship is always in the process of construction and transformation" (Jelin, 2000, p. 53; Isin \& Wood, 1999). The fuel to sustain that fire is voice: to act as a citizen, demanding to participate in the decisions that affect you. While I recognize the vote is a voice and do not underestimate the importance of the achievement of suffrage where it had been denied, I grow increasingly concerned at the manipulation of that "right" through the rhetoric that accuses people of apathy if they do not vote, or suggests that if they fail to vote, they lose the right to complain. This discourse suggests there exists a singular time and place for the struggle for social justice, and that it is the ballot box on voting day, full stop. As we consider manifestations of "voice," I recommend, as Habermas (2001) has elaborated, we move well beyond vote in our understanding and practice of democracy and citizenship.

\section{Conclusion: Civil Society and Citizenship}

The state is not benevolent. The state is the state (as sportscasters like to say, "It is what it is"). It does not have a morality. Anthropological approaches to the individual components and actors within the state may serve to show us its humanity, its diversity, its lack of uniformity, but still, the state is going to act in the interests of its own self-preservation and authority to govern. If it did otherwise, it would cease — by definition — to be the state. 
State policies have different impacts on the societies they purport to govern, and these may be assessed as positive or negative, moral, or immoral. The institution of citizenship does not protect residents from unjust treatment by their governments. States have enacted very violent policies against their own citizens; my point here is not to excuse or minimize such instances, but to argue for a continuum (rather than a stark distinction) among such actions and those that are apparently less violent. Thinking in terms of a continuum should eliminate descriptions of "good" and "bad" states who "like" or "dislike" their citizens (see Faizullaev, 2007). Regardless of the manner in which a state acts, it is acting towards its self-preservation. Thus, even its most apparently benevolent acts, such as the allocation of rights and privileges, are as strategic as its most violent.

Citizenship is not a gift of the state; at most, the state constitutes only half of the equation in the production of rights. To be a citizen is not to be "good"; it is to be political, to make claims to rights and space (Isin, 2002). In turn, then, I would prefer to emphasize the role of civil society in the process of challenging inequality and struggling for social justice as another form (or, more accurately, the other side of the state's conception) of citizenship (Edwards, 2004), in which the state exists as the tool with which civil society acts. I suggest we focus on the ways in which we may act politically, socially, and economically that are removed from the state's direction: the "citizenship beyond the state" mentioned earlier (Isin, 2007). There are two ways in which this happens: the first disregards the state to the point of ignoring it; the second directly engages and employs it.

Often in direct response to a sense of the absence or recent retraction of the state from social services, we find individuals, communities, and non-governmental agencies stepping into the vacuum to organize and serve the needy. The impact of these actions must be fully acknowledged for the enormous contribution they make. The value of volunteer work to public education, the provision of food, gifts, emotional support of religious institutions (not only for their constituencies, but the society-at-large) and so on, has repeatedly been calculated as equal to contributions of the state. Studies of collective efficacy - the ability of communities to care for themselves, especially to reduce harm (see, for example, Sampson, Raudenbush, \& Earls, 1997) - similarly demonstrate the significance of social organization and regulation.

The second role played by civil society may be found in the demands of the state made by individuals and groups. Recognizing the actual process of producing rights, the relationships and struggles involved, is key to moving away from a perspective of rights as a privilege determined by and in the custody of the state. The state should instead be invoked as an 
instrument of moral authority with powers of enforcement to execute the wishes of the citizens. Such mentalities and commitment lie at the heart of many communities and organizations advocating for "global citizenship." While I am not trying to argue for an over-simplified and allegedly unified force, nor a "global civil society," a phrase for which John Keane (2003) urges a similar caution, I do assert the critical role of citizens in the production of their own governance - and I would argue further that it is in that enacting of that political participation that citizenship is practiced, regardless of formal status. While recruitment and the sharing of information on a global scale may contribute to activists" success, governance or "citizenship" at the global level is neither essential nor critically sound. "Cosmopolitan citizenship" or "global activism" might better capture the essence of the goals and purposes of those seeking to challenge neoliberal globalization and neo-imperialism.

Voting, carrying a passport - these are the so-called "rights" of citizens, often policed discursively into moralized forms of behaviour instead of political engagement that could be disruptive and transformative. The state's harsh response to massive public protest, noted above, reveals how grounded and territorial the struggle for rights remains. As Michael Schudson (1999) has written, "[A public sphere] is the playing field for citizenship; democratic citizenship may bear fruit in the formal act of voting or legislating, but it germinates in the soil of a free public life" (p. 12). Collective action, claiming public space - these are the acts of civilized, politicized people (Edwards, 2004). Their acts constitute citizenship if they address the state and demand rights that may be institutionalized beyond the immediate negotiation of the protest, or if they otherwise create a recognized legitimate space for subjects to participate in the decisions that affect them. Their acts, however small, should never be taken lightly: they could bring about an enduring, fundamental restructuring of the neoliberal order of things, locally and globally, and there is little chance anything else will.

\section{References}

Agamben, G. (2005). State of exception (K. Attell, Trans.). Chicago and London: University of Chicago Press.

Arneil, B. (2007). Global citizenship and empire. Citizenship Studies, 11(3), 301-28.

Backhouse, C. (1999). Colour-coded: A legal history of racism in Canada, 1900-1950. Toronto, Ontario, Canada: University of Toronto Press.

Bakan, J. (2004). The winter 2008 corporation: The pathological pursuit of profit and power. Toronto, Ontario, Canada: Penguin Group.

Basok, T. (2002). Tortillas and tomatoes: Mexican transmigrant harvesters in Canada. Montreal, Quebec, Canada: McGill-Queen's Press.

CBC News. (2006, November 7). Ottawa reviewing rules of dual citizenship: Solberg. Retrieved November 10, 2007, from http://www.cbc.ca/canada/story/2006/11/ 07/dualcitizenship.html

CHANCE. (2007). Retrieved February 6, 2007, from http://www.chance.sa.utoronto.ca/ cconference.htm 


\section{P. B. Wood}

Dauvergne, C. (2004). Sovereignty, migration and the rule of law in global times. Modern Law Review, 67(4), 588-615.

Douglass, F. (1985). The significance of emancipation in the West Indies. Speech, Canandaigua, New York, August 3, 1857, In J.W. Blassingame (Ed.), The Frederick Douglass Papers. Series One: Speeches, Debates, and Interviews, Vol. 3, (pp. 1855-1863). New Haven, CT: Yale University Press.

Edwards, M. (2004). Civil society. Cambridge, MA: Polity.

Faizullaev, A. (2007). Individual experiencing of states. Review of International Studies, $33,531-554$.

Falk, R. (2000). The decline of citizenship in an era of globalization. Citizenship Studies, 4(1), 5-17.

Fanon, F. (1967). Black skin, white masks (C.L Markmann, Trans.). New York: Grove Press.

Frazee, C. (2002). The legal regulation and construction of the gendered body and of disability in Canadian health law and policy. Toronto, Ontario, Canada: National Network on Environments and Women's Health.

Government News Network. (2007). Retrieved December 5, 2007 from, http:// www.gnn.gov.uk/Content/Detail.asp?ReleaseID $=336084 \&$ NewsAreaID $=2$

Habermas, J. (2001). The postnational constellation: Political essays. Cambridge: MIT Press.

Halliday, F. (2000). Global governance: Prospects and problems. Citizenship Studies, 4(1), 19-33.

Harring, S. (1998). White man's law: Native people in nineteenth-century Canadian jurisprudence. Toronto, Ontario, Canada: University of Toronto Press.

Held, D. (2002). Law of states, law of peoples: Three models of sovereignty. Legal Theory, 8, 1-20.

Home Office (UK). (2007). Retrieved December 2, 2007, from http:// www.ind.homeoffice.gov.uk/applying/nationality/goodcharacter

Isin, E. (2002). Being political: Genealogies of citizenship. Minneapolis, MN: University of Minnesota Press.

Isin, E. (2007). City, state: Critique of scalar thought. Citizenship Studies, 11(2), 211228.

Isin E., \& Rygiel, K. (2006). Abject spaces: Frontiers, zones and camps. In E. Daupinee \& C. Masters (Eds.), The logics of biopower and the war on terror: Living, dying, surviving (pp. 181-203). Houndmills, Basingstoke, Hampshire, UK: Palgrave.

Isin, E., \& Turner, B. (2007). Investigating citizenship: An agenda for citizenship studies. Citizenship Studies, 11(1), 5-17.

Isin, E., \& Wood, P. (1999). Citizenship and identity. London: Sage.

Jacobson, D. (1996). Rights across borders: Immigration and the decline of citizenship. Baltimore: Johns Hopkins University Press.

Janoski, T. (1998). Citizenship and civil society: A framework of rights \& obligations in liberal, traditional and social democratic regimes. Cambridge, UK, and New York: Cambridge University Press.

Jelin, E. (2000). Towards a global environmental citizenship? Citizenship Studies, 4(1), 47-63.

Keane, J. (2003). Global civil society? Cambridge, UK, and New York: Cambridge University Press. 
Krasner, S. (1999). Sovereignty: Organized hypocrisy. Princeton, NJ: Princeton University Press.

Lister, R. (2003). Citizenship: Feminist perspectives (2nd ed.). New York: NYU Press.

MacKinnon, C. (1991). Toward a feminist theory of the state. Cambridge, MA: Harvard University Press.

Marshall, T.H. (1950). Citizenship and social class. Cambridge, MA: Cambridge University Press.

McCarthy, J., \& Prudham, S. (2004). Neoliberal nature and the nature of neoliberalism. Geoforum, 35, 275-283.

Muetzelfeldt, M., \& Smith, G. (2002). Civil society and global governance: The possibilities for global citizenship. Citizenship Studies, 6(1), 55-75.

Microsoft. (2007). Global citizenship at microsoft. Retrieved December 6, 2007, from www.microsoft.com/about/corporatecitizenship/citizenship/default.mspx

Mountz, A. (2003). Human smuggling, the transnational imaginary, and everyday geographies of the nation-state. Antipode, 35(3), 622-644.

Neumann, I.B. (2004). Beware of organicism: The narrative self of the state. Review of International Studies, 30, 259-267.

Oxfam Education. (2007). Global citizenship. Retrieved December 6, 2007 from, www.oxfam.org.uk/education/gc

Peck, J. (1996). Work-place: The social regulation of labor markets. New York: Guilford Press.

Peck, J. (2001). Neoliberalizing states: Thin policies/hard outcomes. Progress in Human Geography, 25(3), 445-455.

Pratt, G. (2005). Abandoned women and spaces of the exception. Antipode, 37(5), $1053-$ 1078.

Prunier, G. (1995). The Rwanda crisis: History of a genocide. New York: Columbia University Press.

Sampson, R.J., Raudenbush, S.W., \& Earls, F. (1997). Neighbourhoods and violent crime: A multilevel study of collective efficacy. Science, 277, 918-924.

Schudson, M. (1999). The good citizen: A history of American civic life. Cambridge, MA: Harvard University Press.

Smith, M. (2001). Transnational urbanism: Locating globalization. Oxford: Blackwell.

Sonnenfeld, D., \& Mol, A. (2002). Globalization and the transformation of environmental governance. American Behavioral Scientist, 45(9), 1318-1339.

Wainwright, J., Prudham, S., \& Glassman, J. (2000). The battles in Seattle: Microgeographies of resistance and the challenge of building alternative futures. Environment and Planning D: Society and Space, 18(1), 5-13.

Walcott, B. (2003). David, Goliath and the beach-cleaning machine: How a small California town fought an oil giant—and won! Sterling, VA: Capital Books.

Wendt, A. (2004). The state as person in international theory. Review of International Studies, 30, 289-316.

White, M. (2006). The dispositions of 'good' citizenship: Character, symbolic power and disinterest. Journal of Civil Society, 2(2), 111-122.

Wood, P. (2002). Nationalism from the margins. Montreal, Quebec, Canada: McGillQueen's University Press.

Wood, P., \& Gilbert, L. (2005). Multiculturalism in Canada: Accidental discourse, alternate vision, urban practice. International Journal of Urban and Regional Research, 29(3), 679-691. 